\title{
Pemetaan Potensi Pengembangan Produk Natural Uncertainty Contract (NUC) pada Pembiayaan Produktif dan Produk Natural Certainty Contract (NCC) pada Pembiayaan Konsumtif di Bank Syariah
}

\author{
Trimulato \\ Prodi Perbankan Syariah Universitas Muhammadiyah Parepare, Indonesia \\ Email korenpondensi: trimsiuii@yahoo.co.id
}

\begin{abstract}
Abstrak
Perbankan syariah di Indonesia terus mengalami pertumbuhan, terlihat pangsa pasar bank syariah sudah menembus 5 persen. Aset perbankan syariah pada akhir tahun 2016 sebesar 254.184.000.000.000. Pada sisi pembiayaan, porsi konsumtif masih mendominasi dari pembiayaan di bank syariah. Penelitian ini bersifat deskriptif kualitatif, yang akan menguraikan perkembangan akad pembiaayaan NUC dan Pembiayaan NCC di bank syariah kemudian memetakan pembiayaan untuk konsumtif, produktif, dan investasi. Dari hasil penelitian ini menujukkan perkembangan akad NCC di bank syariah sebesar 14,039 persen. Dengan akad murabahah sebesar 133.956.000.000 dan ijarah 8.105.000.000 dan salam 25.000.000. Sedangkan pertumbuhan akad pembiayaan NUC sebesar 23,99 \%. Akad mudharabah sebesar 15.263.000.000 dan musyarakah 71.710.000.000. Pembiayaan konsumtif mendominasi pada pembiayaan di bank syariah sebesar 40,57 persen atau sebesar 100.602.000.000. bank syariah perlu melakukan pemetaan terhadap produk pembiayaan. Akad-akad pembiayaan NCC untuk konsumtif dan akadakad NUC untuk kegiatan produktif (modal kerja dan Investasi).
\end{abstract}

Kata Kunci : Pembiayaan NCC, Pembiayaan NUC, dan Bank Syariah

Saran sitasi: Trimulato. (2019). Pemetaan Potensi Pengembangan Produk Natural Uncertainty Contract (NUC) pada Pembiayaan Produktif dan Produk Natural Certainty Contract (NCC) pada Pembiayaan Konsumtif di Bank Syariah. Jurnal Ilmiah Ekonomi Islam, 5(02), 120-130. doi: http://dx.doi.org/10.29040/jiei.v5i2.386

DOI: http://dx.doi.org/10.29040/jiei.v5i2.386

\section{Pendahuluan}

\subsection{Latar Belakang}

Ide dasar sistem perbankan Islam sebenarnya dapat dikemukakan dengan sederhana.Operasi institusi keuangan Islam terutama berdasarkan pada prinsip PLS (porfitand-loss-sharing bagi untung dan rugi). Prinsip bagi hasil ini dalam keuangan Islam sangat dianjurkan dan merupakan solusi yang pantas dan relevan untuk mengatasi masalah alokasi dana yang terbatas, baik yang berupa dana pinjaman atau tabungan dengan maksud supaya pengelolaan dan pembiayaan bisnis secara efektif dapat tercapai. Bank Islam tidak membebankan bunga, melainkan mengajak partisipasi dalam bidang usaha yang didanai.Para deposan juga sama-sama mendapat bagian dari keuntungan bank sesuai dengan rasio yang telah ditetapkan sebelumnya. Dengan demikian ada kemitraan antara bank Islam dan para deposan di satu pihak, dan antara bank para nasabah investasi sebagai pengelola sumber daya para deposan dalam berbagai usaha produktif dipihak lain (Algaoud:2001). 
Karakteristik sistem perbankan syari'ah yang beroperasi berdasarkan prinsip bagi hasil memberikan alternatif sistem perbankan yang saling menguntungkan bagi masyarakat dan bank, serta menonjolkan aspek keadilan dalam bertransaksi, investasi yang beretika, mengedepankan nilai-nilai kebersamaan dan persaudaraan dalam berproduksi, dan menghindari kegiatan spekulatif dalam bertransaksi keuangan. Dengan menyediakan beragam produk serta layanan jasa perbankan yang beragam dengan skema keuangan yang lebih bervariatif, perbankan syari'ah menjadi alternatif sistem perbankan yang kredibel dan dapat dinimati oleh seluruh golongan masyarakat Indonesia tanpa terkecuali (www.bi.go.id).

Bank syari'ah lebih dikenal dengan sistem bagi hasil yang mempunyai berbagai produk yang menggunakan akad Mudharabah dan Musyarakah, dianggap lebih adil bagi semua pihak. Namun saat ini sepertinya sudah mulai terjadi pergeseran di bank syari'ah, Bank syari'ah lebih senang dan lebih mengunggulkan produk pembiayaan dengan akad Murabahah, yang memberikan hasil yang pasti. Bisa dilihat perbandingan pembiayaan di bank syari'ah dengan menggunakan akad Mudharabah dan akad Murabahah.

Jenis pembiayaan yang ada di bank syariah terbagi dua, yaitu pembiayaan dengan akad Natural Certainty Countract (NCC) dan pembiayaan akad Natural Uncertainty contract (NUC). Akad pembiayaan NCC adalah akad yang memberikan kepastian pengembalian dan keuntungan termasuk kepastian waktu, sedangkan akad pembiayaan NUC adalah akad yang tidak memberikan kepastian pengembalian atau keuntungan. Adapun yang masuk dalam akad pembiayaan NCC adalah jual beli murabahah, jual beli salam, jual beli istisnha', ijarah dan Ijarah Muntahiyya Bit Tamlik (IMBT). Adapun akad pembiayaan yang masuk dalam NUC yaitu akad Mudharabah dan akad Musyarakah.

Risiko bank syariah dalam akad pembiayaan NUC potensial tinggi karena sangat mengandalkan kepercayaan yang sangat tinggi sebagai jaminan moral. Dalam literatur fiqih, kedua produk NUC disebut sebagi produk dengan akad kepercayaan (uqud al-amanah). Praktek moral hazard mencerminkan pengkhianatan terhadap kepercayaan yang diberikan oleh nasabah kepada bank dan kepercayaan bank pada nasabah. Kepercayaan merupakan faktor yang sangat diandalakn oleh bank syariah sebagai nilai yang berbasis ajaran islam. Kedua akad NUC rentan terhadap praktek moral hazard yang dilakukan nasabah maupun oleh manajemen bank jika tidak ada komitmen moral dalam melaksanakan kontrak. Al-qur'an melarang kita menghianati kepercayaan (QS. AlMaidah ayat 1). Oleh karena itu, manajemen bank syariah perlu menunjukkan komitmen konkrit agar nilai-nilai kepercayaan tetap terjaga selama jangka waktu perjanjian (Alwi:2013).

Bank syari'ah lebih dikenal dengan sistem bagi hasil yang mempunyai berbagai produk yang menggunakan akad Mudharabah dan Musyarakah, dianggap lebih adil bagi semua pihak. Namun saat ini sepertinya sudah mulai terjadi pergeseran di bank syari'ah, Bank syari'ah lebih senang dan lebih mengunggulkan produk pembiayaan dengan akad Murabahah, yang memberikan hasil yang pasti. Bisa dilihat perbandingan pembiayaan di bank syari'ah dengan menggunakan akad NCC dan akad NUC.

\section{Tabel 1.1}

Produk Pembiayaan di Bank Syariah Desember 2015 (OJK:2015)

\begin{tabular}{|c|c|c|c|}
\hline NO & JENIS PEMBIAYAAN & BESAR PEMBIAYAAN & FREKUENSI/ KONTRIBUSI \\
\hline 1 & AKAD PEMBIAYAAN NCC & & \\
& - MURABAHAH & 122.111 & \\
& - SALAM & - & \\
& $-\quad$ ISTISNHA' & 770 & \\
& $-\quad$ IJARAH & 10.631 & $63,868 \%$ \\
& $-\quad$ IMBT & - & \\
& TOTAL & 133.512 & \\
\hline
\end{tabular}


Jurnal Ilmiah Ekonomi Islam, 5(02), 2019, 122

\begin{tabular}{|c|c|c|c|}
\hline NO & JENIS PEMBIAYAAN & BESAR PEMBIAYAAN & FREKUENSI/ KONTRIBUSI \\
\hline 2 & AKAD PEMBIAYAAN NUC & & \\
& $-\quad$ MUDHARABAH & 14.820 & \\
& $-\quad$ MUSYARKAH & 60.713 & $36,132 \%$ \\
\hline 3 & TOTAL & 75.533 & $100 \%$ \\
\hline
\end{tabular}

Sumber: OJK, Data Statistik Perbankan Syariah (Data diolah)

* Dalam Milyar Rupiah

Dari data diatas menunjukkan bahwa dari total pembiayaan di bank syariah desember 2015 sebesar 209.045.000.000.000 masih didominasi penyaluran pembiayaan dengan akad NCC yaitu dengan kontribusi sebesar 63,828 persen. Sedangkan porsi penyaluran pembiayaan dengan akad NUC masih sangat minim dibawah 50 persen yaitu hanya dikisaran 36,132 persen. Padahal kita ketahui bahwa bank syariah itu lebih dikenal sebagai bank bagi hasil bukan bank jual beli. Maka dari itu perlu didorong agar bank syariah bisa mengembalikan jati dirinya sebagai bank bagi hasil. Bank syariah sebagai lembaga keuangan syariah perlu memperlihatkan eksistensinya kepada masyarakat dalam meningkatkan pembiayaan dengan bagi hasil. Diperlukan segmen yang tepat bagi bank syariah untuk berani memberikan pembiayaan dengan akad NUC. Akad NUC betul sangat berisiko tapi juga jangan diabaikan bahwa dengan Bank syariah memberikan NUC maka besar bisa memberikan keuntungan yang lebih besar. Saat ini makin tumbuh dan diminati sektor usaha UMKM dengan beragam jenis kegiatan.

Konon katanya jika dihitung pendapatan rata-rata masyarakat Indonesia sama besarnya pendapatan rata-rata Negara maju. Hanya saja di Indonesia sebagian pihak kekayaannyanya menjulang naik setinggi langit sedangkan ada pihak yang amat memprihatinkan tidak mampu memenuhi kebutuhan primer. Hal semacam ini yang tidak berlaku dalam ekonomi islam, pemberdayaan masyarakat guna pengembangan sektor rill harus ditingkatkan dan peran masyarakat dalam tataran ekonomi domestik harus mendapatkan perhatian lebih dari semua pihak. Ekonomi domestik adalah ekonomi kita yang sebenarnya, tidak akan ada campur tangan dari Negara lain sehingga jika terjadi masalah ekonomi dengan Negara lain maka tidak memberikan dampak apapun bagi Negara ini. Terbukti jika terjadi krisis ekonomi dunia maka perekonomian domestik menjadi perhatian dan solusi mengatasinya, sebab tidak terkena dampaknya. Jadi sebaiknya ekonomi di sektor rill khususnya tataran domestik harus menjadi perhatian bersama terutama bagi pemerintah. Peluang tetap terbuka dari sejumlah keunggulan yang kini ada dalam perekonomian Indonesia, seperti pasar dalam negeri yang besar, peluang investasi yang masih terbuka luas, dan sejumlah produk unggulan di pasar ekspor. Adanya intervensi pemerintah dalam ekonomi islam terhadap perekonomian sangat dibutuhkan, sebab Negara menjadi wadah terciptanya kesejahteraan ummat manusia. Dalam kepemilikan individu tidaklah bersifat mutlak, namun kepemilikan itu dibatasi oleh beberapa hal. Dalam beberapa kondisi, negara mempunyai hak intervensi terhadap kepemilikan, hak untuk membatasi atau mengatur kepemilikan itu dalam kehidupan masyarakat (Al-Mishri:2006). Perekonomian domestik dalam pengembangannya juga dibutuhkan pihak yang memberikan kemudahan dalam permodalan sehingga pemberdayaan masyarakat dapat tercipta.

Dari uraian ini menjadi sangat penting bagi bank syariah untuk bisa berkontribusi dalam mengembangkan ekonomi domestik khusunya bagi Usaha Kecil dan Menengah (UMKM). Perlu buat desain produk yang bisa memberi jalan bagi bank syariah untuk bisa bersatu mengembangkan usaha kecil dan menenghah (UMKM). Saat ini bermuculan upaya bank syariah untuk bisa memmberikan pembiayaan pada sektor UMKM. Krisis yang melanda bangsa Indonesia telah 
meluluh lantakkan segala sendi-sendi kehidupan termasuk juga sektor perbankan yang juga di pandang sebagai salah satu pemicunya, yaitu dengan disalurkannya kredit-kredit yang salah sasaran. Krisis membuktikan bahwa usaha kecil menengah yang jumlah sangat banyak mampu bertahan menghadapi krisis tersebut secara mandiri. Disaat perekonomian kini mulai menunjukkkan geliat untuk bangkit kembali, usaha kecil menengah nampaknya seolah kembali terlupakan, terutama lagi dengan banyak masuk dan beroperasinya usaha asing - termasuk perbankan asing pasca periode penjualan asetaset perbankan nasional. Perbankan syariah yang telah dirintis sejak tahun 1992 nampaknya kini dapat menjadi harapan baru bagi pengembangan usaha kecil menengah, khususnya dalam pengadaan modal kerja. Dari peristiwa krisis yang telah melanda bangsa Indonesia tersebut telah menciptakan kemiskinan bagi sebagian kalangan masyarakat kita yang sifatnya terstruktur, melalui pemberdayaan perbankan syariah ini harapan kita akan bisa menangani kemiskinan dengan menghilangkannya melalui proses trickle down effect. Akibatnya kemungkinan terjadinya ketimpangan distribusi dan akses sumber daya ekonomi. Karena pendekatan ini butuh biaya besar dan harus ditanggung oleh negara (mengandalkan pinjaman luar negeri). Untuk mengatasi permasalahan yang telah terjadi selama ini terhadap Negara kita yang selalu mengandalkan ketergantungan kepada bantuan dari luar nergeri salah satu langkah yang dianggab efektif adalah menggunakan keuangan mikro sebagai metode utama. Kontribusi pendekatan ini terdiri dari diversifikasi pelaku utama pembangunan adalah masyarakat, pembiayaan pembangunan yang menggunakan sumber keuangan masyarakat sendiri serta menerapkan pendekatan pembangunan yang memiliki potensi untuk berlanjut (sustainable). Beranjak dari permasalahan itu, kita sebagai Subyek yang akan menentukan masa depan bangsa kita tidak akan mingkin bergantung secara terus menerus terhadap upaya- upaya tersebut. Kita harus berupaya mencari terobosan- terobosan lain yang justru memberikan harapan yang lebih menjanjikan terhadap masa depan perekonomian kita. Saat sekarang ini seiring dengan berkembangnya pola pikir masyarakat Indonesia pada umumnya, telah bisa melahirkan terobosanterobosan baru dalam rangka pengembangan ekonomi bangsa, dari banyak terobosanterobosan tersebut salah satunya dapat kita amati dari segi perkembangan sector Asaha Kecil dan Menengah (www.kompasiana.com).

Dari uraian diatas peneliti merasa tertarik untuk melakukan penelitian lebih lanjut mengenai pembiayaan NCC dan NUC di bank syariah, serta sasaran dari kegiatan pembiayaan tersebut. Tidak semua pembiayaan di bank syariah harus menggunakan akad NCC dan tidak semua harus menggunakan akad NUC. Tetapi harus sesuai dari tujuan dari pembiayaan yang dibutuhkan oleh nasabah. Adapaun judul penelitian yang diangkat adalah Pemetaan Potensi Pengembangan Produk Pembiayaan NCC Bagi Konsumtif dan Produk Pembiayaan NUC bagi Produktif di bank syariah.

\subsection{Telaah Pustaka}

Sebelum melakukan penelitian, peneliti berusaha menelaah literatur karya ilmiah sebelumnya yang berkaitan dengan judul yang diteliti. Hasil penelitian-penelitian yang pernah dilakukan sebelumnya perlu dikemukakan sebagai bahan perbandingan dengan penelitian yang dilakukan penulis. Adapun karya-karya ilmiah yang relevan dengan topik yang peneliti angkat antara lain:

Yuli Anisah dalam penelitiannya yang berjudul Pengaruh Sistem Profit Sharing Terhadap Keinginan Nasabah Untuk Berinvestasi Pada Baitul Maal Wa Tamwil (BMT) Di Kota Banda Aceh, menyimpulkan Profit Sharing membuat keinginan berinvestasi menunjukkan sebesar 0,452 pada taraf signifikansi 1 persen. pengujian hipotesis diperoleh bahwa Ha diterima yang berarti bahwa antara $\mathrm{x}$ dengan $\mathrm{y}$ terdapat pengaruh yang signifikan. Sistem bagi hasil di lembaga keuangan syari'ah memberi mempengaruhi 


\section{Jurnal Ilmiah Ekonomi Islam, 5(02), 2019, 124}

minat para nasabah untuk menanamkan menabung dilembaga keuangan syariah BMT.Dari tahun ketahun, dengan penambahan jumlah nasabah yang terus menerus (Anisah:2012).

Dini Arwati dalam tulisannya menyebutkan bahwa Perbankan Syariah lebih tepat memilih mitra kerjanya kepada UMKM yang jumlahnya banyak, sesungguhnya pemahaman mengenai ekonomi syariah, penerapan akuntansi syariah, penyaluran pembiayaan syariah, dan penghimpunan dana syariah lebih cepat dan sesuai sasaran. Untuk menetapkan besarnya bagi hasil dalam pembiayaan syariah ini tentunya diperlukan perangkat yang standar. Informasi ini biasanya disebut dengan Laporan Keuangan. Dalam hubungan perbankan syariah maupun non syariah dengan UKM, maka dari pihak UKM harus bisa menyediakan laporan keuangan yang dapat diandalkan (Arwati:2013).

Muslimin Kara dalam tulisannya menyebutkan perkembangan pembiayaan perbankan syariah dalam upaya pengembangan UMKM di Kota Makassar selama tahun 20102011 mengalami peningkatan yang berfluktuasi. Hal tersebut mencerminkan bahwa peran serta pembiayaan perbankan syariah dalam peningkatan usaha mikro kecil dan menengah (UMKM) di Kota Makassar belum optimal. Secara rata-rata perkembangan pembiayaan perbankan syariah selama periode Januari Desember 2010 sebesar 14,23\%, sedangkan periode Januari - September tahun 2011 sebesar 18,43\% (Kara: 2013).

Herni Ali dan Miftahurrohman dalam tulisannya dalam jurnal esensi yang berjudul Determinan yang mempengaruhi pembiayaan murabahah pada perbankan syariah di indonesia, menyimpulkan bahwa dana pihak ketiga, return on asset (ROA), inflasi, dan PDB bepengaruh positif terhadap pembiayaan murabahah. Sedangkan CAR dan tingkat suku bunga kredit berpengaruh negatif terhadap pembiayaan murabahah. Kemudian, NPF dan BOPO tidak berpengaruh terhadap jumlah pembiayaan murabahah(Herni:2016).
Marwini dalam tulisannya pada jurnal AzZarqa' yang berjudul Aplikasi Kontraktual Pembiayaan Murabahah Pada Bank Syariah menyebutkan bahwa Aplikasi dan mekanisme kontrak pembiayaan murabahah KPR Syariah ini, dilihat dari syarat rukun kontrak, telah memenuhi syarat-rukun sahnya kontrak (akad jual beli) dalam fikih muamalah. Yaitu pertama, adanya para pihak yang memenuhi syarat tamyiz Kedua,adalah pernyataan kehendak dari para pihak (shighatul 'aqdi) yang berbentuk ijab qabul Ketiga, adalah objek akad (mahallul 'aqdi), berupa rumah, dan keempat adalah sesuai dengan syariah. Dalam transaksi ini ada dua akad yang dilakukan, yaitu akad wakalah dan akad murabahah Prosedur yang dilakukan dalam mekanisme Pembiayaan KPR Syariah adalah bank sebagai penjual barang telah sesuai dengan prinsip jual beli murabahah, yaitu memberitahukan secara jujur harga pokok dan ditambah margin keuntungan (Marwini:2012).

\subsection{Akad Pembiayaan}

\subsubsection{Akad Pembiayaan Natural Uncertanty Contract (NUC)}

Mudharabah berasal dari kata adhdharbu fil ardhi, yaitu berpergian untuk urusan dagang. Firman Allah dalam surat 73 ayat 20. "Mereka bepergian di muka bumi mencari karunia Allah.' 'Disebut juga qiradh yang berasal dari kata al-qardhu yang berarti al-qath'u (potongan), karena pemilik memotong sebagian hartanya untuk diperdagangkan dan memperoleh sebagian keuntungan (Sudarsono:2005).

Secara teknis mudharabah adalah akad kerjasama usaha antara dua pihak dimana pihak pertama (shahibul maal) menyediakan seluruh modal, sedangkan pihak lainnya menjadi pengelola. Keuntungan usaha secara mudharabah dibagi menurut kesepakatan yang dituangkan dalam kontrak, sedangkan apabila rugi ditanggung oleh pemilik modal selama kerugian itu bukan akibat kelalaian si pengelola. Seandainya kerugian itu diakibatkan karena kecurangan atau kelalaian si pengelola, si pengelola harus bertanggungjawab atas kerugian tersebut (Sudarsono:2005). 


\subsubsection{Akad Natural Certainty Contract (NCC)}

Murabahah dalam literatur klasik menurut Ayub (2007; 215-216) adalah berasal dari kata "Ribh" yang artinya laba, keuntungan atas tambahan.dalam murabahah, penjual harus menyebutkan keuntungan. Transaksi seperti ini telah dipraktekkan dalam masa sebelum peradaban Islam (Widodo:2014).

Murabahah adalah jual beli barang pada harga asal dengan tambahan keuntungan yang disepakati antara pihak bank dan nasabah. Dalam murabahah, penjual menyebutkan harga pembelian barang kepada pembeli, kemudian ia mensyaratkan atas laba dalam jumlah tertentu. Pada perjanjian murabahah, bank membiayai pembelian barang yang dibutuhkan oleh nasabahnya dengan membeli barang itu dari pemasok, dan kemudian menjualnya kepada nasabah dengan harga yang ditambah keuntungan atau di-mark-up. Dengan kata lain, penjualan barang kepada nasabah dilakukan atas dasar cost-plust profit (Sudarsono:2008).

Pengertian Bai'al-Murabahah merupakan kegiatan jual beli pada harga pokok dengan tambahan keuntungan yang disepakati. Dalam hal ini penjual harus terlebih dulu memberitahukan harga pokok yang ia beli ditambah keuntungan yang diinginkannya. Murabahah bitsaman ajil atau lebih dikenal sebagai Murabahah berasal dari kata ribhu (keuntungan) adalah transaksi jual beli dimana bank menyebut jumlah keuntungan yang diambil dari barang yang akan dibeli nasabah terserbut. Bank bertindak sebagai penjual, sementara nasabah sebagai pembeli. Harga jual adalah harga beli bank dari pemasok ditambah keuntungan. Kedua pihak harus menyepakati harga jual dan jangka waktu pembayaran. Harga jual dicantumkan dalam akad jual beli dan jika telah disepakati tidak dapat berubah selama berlakunya akad (www.nuansa.net). Dalam perbankan, Murabahah lazimnya dilakukan dengan cara pembayaran cicilan (bitsaman ajil). Dalam transaksi ini barang diserahkan segera setelah akad, sedangkan pembayaran dilakukan secara tangguh/cicil.
Hukum jual beli dengan cara kredit adalah boleh dengan menetapkan harga suatu barang secara total lebih dahulu ketika terjadi transaksi tanpa mengaitkan dengan bunga dalam tempo baik kedua belah pihak melakukan transaksi melakukan persetujuan persentase bunga atau mengaitkan bunga dengan yang berlaku pada umumnya. Masalah ini elah dibahas dalam ketetapan Konvensi Fiqih Islami pad Organisasi Kongres Islami yang dilaksanakan di Jeddah, yaitu keputusan nomor 5 (2/6), tanggal 1723/1/1410 H dan keputusan nomor 5/ (2/6), tanggal 12/11/1412 $\mathrm{H}$ yang dilaksankan di Jeddah (Abdullah:2009).

\section{Metode Penelitian}

\subsection{Jenis Penelitian}

Jenis penelitian yang digunakan dalam tulisan ini adalah dengan menggunakan Library Reserch (Studi Pustaka) yang diperoleh dari beberapa sumber yang relevan dengan tema yang diangkat.

Penelitian ini bersifat deskriptif kualitatif yang artinya menggambarkan suatu subyek penelitian. Dalam hal ini adalah bentuk produk pembiayaan dengan akad NUC dan NCC di bank syari'ah. Kemudian tentang potensi pengembangan produk pembiayaan dengan akad NUC dan NCC di bank syari'ah sesuai tujuan pembiayaan produktif dan konsumtif.

\subsection{Jenis Data}

Jenis data yang digunakan dalam tulisan ini adalah data kualitatif yang bersumber dari data primer dan data sekunder. Data primer berupa sumber data yang langsung memberikan data kepada peneliti atau data yang diperoleh langsung dari lapangan (objek penelitian), sedangkan data sekunder adalah sumber data yang tidak langsung memberikan data kepada pengumpul data (peneliti) atau data yang diambil peneliti sebagai pendukung atas penelitian secara ilmiah yaitu dengan melakukan studi pustaka (penelusuran melalui buku, artikel, jurnal, majalah, internet dan sumber lainnya) (Farizal:2010). 
Data-data yang digunakan penulis antara lain:

a. Teori-teori yang peneliti ambil dari berbagai literatur.

b. Pengambilan data-data dari hasil yang telah tersaji dari suatu lembaga.

\subsection{Teknik Pengumpulan Data}

Teknik pengumpulan data yang diperlukan dalam tulisan ini adalah dengan menggunakan beberapa metode yaitu:

\subsubsection{Studi Kepustakaan}

Metode ini digunakan untuk menggali dasardasar teori yang terkait produk pembiayaan dengan akad NUC dan NCC di Bank Syariah dan terkait dengan tujuan pembiayaan yaitu produktif dan konsumtif.

\subsubsection{Pengamatan}

Setiap data yang didapatkan dari berbagai sumber diamati dan dianalisa terkait dengan kondisi produk pembiayaan NUC dan NCC di bank syariah.

\subsection{Analisis data}

Metode analisis data yang digunakan adalah dengan menggunakan pendekatan kualitatif deskriptif yaitu dengan cara memaparkan metode teori produk pembiayaan dengan akad NUC dan NCC di bank syari'ah, melalui potensi pengembangan akad pembiayaan NUC dan NCC dalam memberikan pembiayaan sesuai dengan porsinya. Kemudian bagaimana penerapannya di bank syari'ah sebagi produk yang bisa disalurkan bagi usaha masyarakat.

Penelitian kualitatif adalah prosedur penelitian yang menghasilkan data deskriptif berupa kata-kata tertulis atau lisan dari orangorang dan keadaan yang diamati. Penelitian kualitatif adalah metode penelitian yang digunakan untuk meneliti pada kondisi objek yang alamiah, (sebagai lawannya adalah eksprimen) dimana peneliti adalah sebagai instrument kunci, teknik pengumpulan data dilakukan secara trianggulasi (gabungan), analisa data bersifat induktif dan hasil dari penelitian kualitatif lebih bersifat makna daripada generalisasi.

\section{Hasil Penelitian}

\subsection{Perkembangan Akad Natural Uncertanty Contract (NUC) di Bank Syariah}

\section{Tabel 3.1}

Perkembangan Akad Pembiayaan NUC di Bank Syariah Tahun 2016

\begin{tabular}{|c|c|c|c|c|}
\hline NO & JENIS AKAD NUC & TAHUN 2015 & TAHUN 2016 & PERTUMBUHAN \\
\hline 1 & MUDHARABAH & 14.815 & 15.263 & $3 \%$ \\
\hline 2 & MUSYARAKAH & 55.331 & 71.710 & $29,601 \%$ \\
\hline $\mathbf{3}$ & TOTAL & $\mathbf{7 0 . 1 4 6}$ & $\mathbf{8 6 . 9 7 3}$ & $\mathbf{2 3 , 9 9 \%}$ \\
\hline
\end{tabular}

Sumber: OJK, Statistik Perbankan Syariah Desember 2016 (data Diolah)

*dalam Milyar Rupiah

Dari data diatas menunjukkan adanya pertumbuhan pada produk pembiayaan dengan akadakad NUC di Bank Syariah pada periode 2015 sampai dengan periode 2016. Data menunjukkan bahwa pertumbuhan ditunjukkan oleh akad musyarakah yang tumbuh sebesar
29,601 persen. Kemudian akad mudharabah hanya tumbuh sebesar 3 persen. Secara total pembiayaan dengan akad NUC pada tahun 2016 sebesar 86.973.000.000 atau tumbuh sebesar 23,99 persen. 
Jurnal Ilmiah Ekonomi Islam, 5(02), 2019, 127

\subsection{Perkembangan Akad Natural Certanty Contract (NCC) di Bank Syariah}

Tabel 3.2

Pertumbuhan Produk Pembiayaan NCC di Bank Syariah

\begin{tabular}{|c|c|c|c|c|}
\hline NO & NAMA PRODUK & $\begin{array}{c}\text { DESEMBER } \\
2015\end{array}$ & $\begin{array}{c}\text { DESEMBER } \\
2016\end{array}$ & PERTUMBUHAN \\
\hline 1 & MURABAHAH & $\mathbf{1 1 5 . 6 0 5}$ & 133.956 & $\mathbf{1 6 \%}$ \\
\hline 2 & IJARAH & $\mathbf{8 . 9 7 2}$ & $\mathbf{8 . 1 0 5}$ & $\mathbf{- 9 , 6 6 3 \%}$ \\
\hline 3 & SALAM/ & 120 & 25 & $-\mathbf{7 9 , 1 6 7}$ \\
& ISTISNHA & & & \\
\hline 4 & TOTAL & 124.577 & 142.086 & $\mathbf{1 4 , 0 3 9 \%}$ \\
\hline
\end{tabular}

Sumber: OJK, Statistik Perbankan Syariah Desember 2016 (data Diolah) *dalam Milyar Rupiah

Dari data diatas menunjukkan adanya perkembangan produk pembiayaan (financing) dengan akad NCC yang terjadi di bank syariah pada periode desember 2015 sampai dengan desember 2016. Data menunjukkan secara pertumbuhan akad pembiayaan murabahah mengalami pertumbuhan tersebsar yaitu tumbuh sebesar 16 persen. Adapaun akad Ijarah mengalami penurunan sebesar $-9,663$ persen dan akad salam dan istisnha' juga mengalami penurunan sebesar -79,167. Adapun total pembiayaan dengan akad NCC pada periode desember 2016 sebesar 142.086.000.000 atau tumbuhsebesar 14,039 persen.

\subsection{Pemetaan Akad NUC Untuk Pembiayaan} Produktif dan Akad NCC Untuk Pembiayaan Konsumtif.

Pembiayaan merupakan salah satu tugas pokok bank, yaitu pemberian fasilitas penyediaan dana untuk memenuhi kebutuhan pihak-pihak yang merupakan defisit unit. Menurut sifat penggunaannya, pembiayaan dapat dibagi menjadi:(Nurkholis:2008)

a. Pembiayaan konsumtif, yaitu pembiayaan yang digunakan untuk memenuhi kebutuhan konsumsi, yang akan habis digunakan untuk dipakai memenuhi kebutuhan.

b. Pembiayaan produktif, yaitu pembiayaan yang ditujukan untuk memenuhi kebutuhan produksi dalam arti luas, yaitu untuk peningkatan usaha, baik usaha produksi, perdagangan, maupun investasi.
Menurut keperluannya, pembiayaan produktif dapat dibagi menjadi;

a. Pembiayaan modal kerja, yaitu pembiayaan untuk memenuhi kebutuhan (1) peningkatan produksi, baik secara kuantitatif, yaitu jumlah hasil produksi, maupun secara kualitatif, yaitu peningkatan kualitas atau mutu hasil produksi; dan (2) untuk keperluan perdagangan atau peningkatan utility of place dari suatu barang.

b. Pembiayaan investasi, yaitu untuk memenuhi kebutuhan barang-barang modal (capital goods) serta fasilitas-fasilitas yang erat kaitannya dengan itu.

Bank syariah tidak pernah meminjamkan uang tetapi menjual barang kepada nasabah dengan memberikan fasilitas untuk mencicil harga barang. Bank syariah menyewakan barang kepada nasabah untuk jangka waktu tertentu. Untuk memperoleh barang yang dijual atau disewakan kepada nasabah itu, bank syariah membeli dari pemasok barang. Tegasnya, nasabah tidak pernah memperoleh dana berupa pinjaman dari bank syariah. Modus operandi bank syariah yang demikian itu adalah karena bank syariah tidak boleh membebankan bunga kepada nasabah. Artinya, karena berlakunya larangan memberikan pinjaman uang dengan bunga, maka bank syariah tidak memberikan fasilitas pemberiaan dana dengan langsung kepada nasabah seperti halnya bank konvensional, tetapi melalui modus operandi lain.(Remy:2014). 
Tabel 3.3

Penyebaran Produk Pembiayaan di Bank Syariah Tahun 2016

\begin{tabular}{|c|c|c|c|}
\hline NO & JENIS PENGGUNAAN & TAHUN 2016 & Frekuensi \\
\hline 1 & $\begin{array}{l}\text { MODAL KERJA } \\
\text { a. UMKM } \\
\text { b. } \\
\text { Bukan UMKM }\end{array}$ & $\begin{array}{rr}\text { a. } & 35.827 \\
\text { b. } & 51.536 \\
\mathbf{8 7 . 3 6 3} & \\
\end{array}$ & $35,22 \%$ \\
\hline 2 & 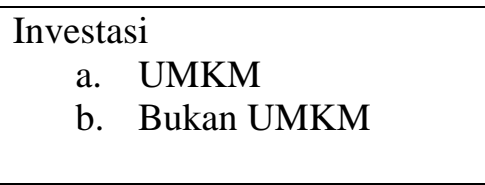 & $\begin{array}{rr}\text { a. } & 18.703 \\
\text { b. } & 41.339 \\
\mathbf{6 0 . 0 4 2} & \end{array}$ & $24,21 \%$ \\
\hline 3 & Konsumsi & 100.602 & $40,57 \%$ \\
\hline & JUMLAH & 248.007 & $100 \%$ \\
\hline
\end{tabular}

SUMBER : OJK, SPS April 2017 (Data diolah)

*Dalam Milyar Rupiah

Dari data diatas menujukkan bahwa porsi pembiayaan yang diberikan oleh bank syariah masih didominasi oleh pembiayaan dengan pola konsumtif yaitu sebesar 100.602.000.000 atau sebesar 40,57 persen. Sedangkan untuk porsi modal kerja sebesar 35,22 persen dan Investasi hanya sebesar 24,21 persen. Sejalan dengan akad pembiayaan yang digunakan bank syariah masih didominasi oleh akad dengan pembiayaan Natural Ceratinty Contract (NUC). Seharusnya dengan pola pembagian jenis pembiayaan bank syariah mampu menempatkan pola akad pembiayaan yang akan diberikan sesuaikan dengan karakter dari akadnya.

Jika produk pembiayaan untuk keperluan konsumsi maka akad yang tepat diberikan oleh adalah akad dengan skema NCC. Sesuai dengan karakter dari akad NCC yang memberikan kepastian pengembalian dan keuntungan baik dari segi waktu maupun besaran keuntungan yang diperoleh.

Berbeda dengan pembiayaan yang bertujuan keperluan Investasi dan Modal kerja, maka akad yang tepat adalah akad dengan skema NUC, sesuai dengan karakternya Investasi dan Modal kerja untuk tujuan bisnis, tidak bisa ditentukan diawal keuntungannya dan pendapatannya tergantung dari pendapat riil dari usaha atau investasi yang diperoleh nasabah. Sehingga kareter ini sejalan dengan NUC yang tidak boleh memberikan kepastian keuntungan atau pendapatan nasabah bagi perbankan syariah. Besarnya pendapatan tidak bisa disepakati

nominalnya hanya dapat disepakati nisbahnya (porsinya) jika mendapatkan keutungan.

Bank syariah sudah harus bisa memetakan porsi pembiayaan yang akan diberikan kepada nasabanhya, serta memahami skema dan karakter tujuan pembiayaan yang diberikannya. Jika pembiayaan untuk konsumsi maka akad yang tepat adalah akad Natural Certainty Contract (NCC) yang terdiri dari akad Murabahah (jualbeli), akad Ijarah (Sewa), dan akad Ijarah Muntahiya Bittamlik (IMBT). Jika untuk tujuan Investasi dan Modal Kerja maka akad yang tepat digunakan adalah akad Natural Uncertainty Contract (NUC) yang terdiri dari akad mudharabah dan akad musyarakah. Tidak semua pembiayaan harus menggunakan akad NCC apalagi dalam rangka menghindari risiko pada akad NUC, sehingga tujuan investasi dan modal kerja juga diberikan NCC. Kemudian dengan pemetaan bank syariah diharap bisa memberikan lebih banyak pembiayaan produktif dalam bentuk pembiayaan modal kerja dan investasi dengan skema yang tepat NUC.

\section{Kesimpulan}

Pertumbuhan pada produk pembiayaan dengan akadakad NUC di Bank Syariah pada periode 2015 sampai dengan periode 2016. Data menunjukkan bahwa pertumbuhan ditunjukkan oleh akad musyarakah yang tumbuh sebesar 29,601 persen. Kemudian akad mudharabah hanya tumbuh sebesar 3 persen. Secara total pembiayaan dengan akad NUC pada tahun 2016 sebesar 86.973.000.000 atau tumbuh sebesar 23,99 persen. 
Perkembangan produk pembiayaan (financing) dengan akad NCC yang terjadi di bank syariah pada periode desember 2015 sampai dengan desember 2016. Data menunjukkan secara pertumbuhan akad pembiayaan murabahah mengalami pertumbuhan tersebsar yaitu tumbuh sebesar 16 persen. Adapaun akad Ijarah mengalami penurunan sebesar -9,663 persen dan akad salam dan istisnha' juga mengalami penurunan sebesar 79,167. Adapun total pembiayaan dengan akad NCC pada periode desember 2016 sebesar 142.086.000.000 atau tumbuh sebesar 14,039 persen.

Tujuan dari pembiayaan di bank syariah terdiri dari tiga yaitu untuk keperluan konsumtif, keperluan modal kerja, dan keperluan investasi. Keperluan konsumtif masih menjadi dominan dari pembiyaan yang diberikan oleh bank syariah yaitu sebesar 40,57 persen, sedangkan untuk modal kerja hanya 35,22 persen dan investasi sebesar 24,21 persen. Hal ini sejalan dengan akad pembiayaan yang dominan di bank syariah masih didominasi akad NCC dalam hal ini adalah akad murabahah sebesar 63,89 persen. Bank syariah harus melakukan pemetaan terhadap produk pembiayaan yang dimilkinya jenis tujuan pembiayaan harus disesuaikan dengan akad yang dimilikinya. Jika tujuannya konsumsi maka akad yang tepat adala NCC dan jika pembiayaan bertujuan untuk modal kerja dan investasi maka akad yang tepat adalah akad NUC.

Hal perlu dilakukan agar bank syariah bisa memberikan pembiayaan lebih yang bersifat produktif. Kemudian untuk bisa meningkatkan jumah penggunaan pembiayaan NUC yang menjadi karakter sekaligus pembeda dengan produk konvensional. Jika bank syariah banyak melakukan pembiayaan produktif dan menerapkan pembiayaan dengan akad NUC maka keberadaanya akan lebih terasa dan bermanfaat bagi orang banyak.

\section{Daftar Pustaka}

Algaoud Latifa M. dan Mervyn K. Lewis. 2001. Perbankan Syariah, Prinsip, Praktik, Prospek, Jakarta: PT. Serambi Ilmu Semesta.

Abdul, Al-Mishri Sami'. 2006. Pilar-Pilar Ekonomi Islam. Yogyakarta: Pustaka Pelajar.

Ali, Herni dan Miftahurrohman. 2016. Determinan Yang Mepengaruhi Pembiayaan Murabahah Pada Perbankan Syariah di Indonesia. Jurnal Esensi: Jurnal Bisnis dan Manajemen. Vol (6)1, Jakarta: Fakultas Ekonomi dan Bisnis Universitas Islam Negeri Syarif Hidayatullah. 2016.

Alwi, Syafaruddin.2013. Memahami Sistem Perbankan Syariah Berkaca Pada Pasar Umar Bin Khattab. 2013. Jakarta: BukuRepublika.

Amah, Nik. Bank Syariah dan UMKM Dalam Menggerakkan Roda Perekonomian Indonesia : Suatu Kajian Literatur, Jurnal Assets : Jurnal Akuntansi dan Pendidikan, Vol 2. No 1. Madiun: Program Studi Pendidikan Akuntansi, FPIPS, IKIP PGRI Madiun.

Anisah, Yuli. 2012. Pengaruh Sistem Profit Sharing Terhadap Keinginan Nasabah Untuk Berinvestasi Pada Baitul Maal Wa Tamwil (BMT) Di Kota Banda Aceh. Jurnal Ekonomi Dan Bisnis Vol 12, No.1. Loksumawe: FEB Politeknik Negeri Louksumawe.

Arwati, Dini. Peran Strategis Ekonomi Berbasis Syariah Dalam Pemberdayaan Ekonomi Sektor Usaha Mikro, Kecil, dan Menengah (UMKM), Ditinjau Dari Penerapan Akuntasi Syariah dan Akuntansi UMKM. Jurnal Ekono-Insentif, Vol 4. No 1. Bandung: Koordinasi Perguruan Tinggi Swasta Wilayah IV Jawa Barat dan Banten.

Bin, Abdullah Muhammad Ath- Thayyar, dkk. 2009. Ensiklopedi Fiqih Muamalah Dalam Pandangan 4 Madzhab. Yogyakarta: Maktabah Al- Hanif.

Direktorat Perbankan Syariah Bank Indonesia, 2008, Kodifikasi Produk Perbankan Syariah. 
Farizal. 2010. Pengembangan Kompetensi SDM Perbankan Syari'ah Melalui Corporate University, Forum Riset Perbankan Syariah II, Yogyakarta. Universitas Muhammadiyah Yogyakarta.

Hakiem, Hilman dan Desi Sulfiaratih Waluyo. 2011. Musyarakah, Mudharabah dan Pertumbuhan Sektor Riil.Jurnal Ekonomi Islam AL-Infaq. Vol.2. No. 1. Bogor: Program Studi Ekonomi Islam Fakultas Ilmu Agama Islam Universitas Ibnu Khaldun.

Iska, Syukri. 2012. Sistem Perbankan Syariah di Indonesia dalam Perspektif Fikih Ekonomi. Yogyakarta: Fajar Media Press.

Mahbub dan Abdi Fauzi Hadiono.2014. Analisis Penerapan Muarabahah Sebagai Bentuk Pembiayaan Pada Bank Syariah Mandiri KCP Rogojampi Banyuwangi. Jurnal Istiqro; Jurnal Hukum Islam, Ekonomi dan Bisnis. Vol 1, No. 1. Banyuwangi: Institut Agama Islam Darussalam Banyuwangi.

Marwini. 2012. Aplikasi Kontraktual Pembiayaan Murabahah Pada Bank Syariah. Jurnal Az-Zarqa' Jurnal Hukum dan Bisnis Islam . Vol 4. No. 2. Yogyakarta: Jurusan Muamalat Fakultas Syariah Universitas Islam Negeri Sunankalijaga Yogyakarta.

Muhamad. 2013. Manajemen Keuangan Syariah Analisis Fiqih dan Keuangan. Yogyakarta: tp.

PERATURAN BANK INDONESIA NOMOR 13/23/PBI/2011 TENTANG PENERAPAN MANAJEMEN RISIKO BAGI BANK UMUM SYARIAH DAN UNIT USAHA SYARIAH.
Prasanto.2013. Faktor Yang Mempengeruhi Pembiayaan Murabahah Pada Bank Umum Syariah di Indonesia. Jurnal AAJ. Vol 2. No.1, Semarang: Prodi Akuntansi Fakultas Ekonomi Universitas Negeri Semarang.

Remy, Sutan Sjahdeini. 2014. Perbankan Syariah Produk-produk dan Aspek-aspek Hukumnya. Jakarta: Kencana. 2014.

Sudarsono, Heri. 2008. Bank \& Lembaga Keuangan Syariah Deskripsi dan Ilustrasi Edisi 3. Yogyakarta: EKONISIA.

Widodo, Sugeng. 2014. Moda Pembiayaan Lembaga Keuangan Islam Perspektif Aplikatif. Yogyakarta. Kaukaba.

http://www.bi.go.id/web/id/Perbankan/Perbanka $n+$ Syariah/, diakses Pada tanggal 14 Juni 2012

http://insco.co.id/?p=1264, diakses pada tanggal 26 Agustus 2014

http://www.kompasiana.com/sangsurya/peranbank-syariah-dalam-mengembangan-usahakecilmenengah_5517d225a333114907b6616c pada tanggal 19 Pebruari 2016

http://porakranjau.wordpress.com/2008/03/27/p otensi-pembiayaan-mudharabah/ Diakses pada tanggal 9 April 2011

http://nuansaonline.net/index.php?option $=$ com_c ontent\&task $=$ view \&id $=163 \&$ Itemid $=30$, Diakses pada tanggal 8 Juni 2013. 